\title{
ANALISIS PERANCANGAN STRUKTUR BETON BERTULANG UNTUK FUNGSI RENTAL OFFICE 30 LANTAI DENGAN PENEKANAN SISTEM RIGID FRAME BERKANTILEVER
}

\author{
Reinhart Bunadi*1, Nasruddin Junus ${ }^{2}$, Imriyanti ${ }^{3}$ \\ ${ }^{* 1}$ Universitas Hasanuddin Makassar, Indosesia, ${ }^{2}$ Universitas Hasanuddin Makassar, \\ Indosesia, ${ }^{3}$ Universitas Hasanuddin Makassar, Indosesia, \\ e-mail: *1reinhartbunadi@gmail.com,2nas_junus@yahoo.com,3imrianti@gmail.com
}

\begin{abstract}
Abstrak__Kota Makassar semakin berkembang ditandai dengan banyaknya bangunan berlantai banyak, termasuk fungsi perkantoran serta ide desain arsitektural bangunan cenderung memvariasikan struktur sebagai daya tarik desainnya, struktur bangunan menjadi perhatian utama.Penelitian ini membahas tentang analisis struktur rigid frame berkantilever gedung kantor sewa 30 lantai dengan material beton bertulang. Analisis bertujuan menentukan detail struktur yang tepat untuk bangunan tersebut dengan program SAP2000 v.14. Penelitian bersifat kuantitatif karena menentukan dimensi struktur. Adapun penelitian bersifat komparatif. Struktur penopang cantilevered slab diberi dua alternatif, yaitu model 1 dan model 2. Terhadap beban-beban nongempa, model 1 lebih stabil sebesar 3,2\%-10,39\% dari model 2. Terhadap beban-beban gempa, model 1 cenderung lebih stabil dengan selisih efisiensi terbesar 37,7\%-45,4\% pada beban gempa respon spektrum. Adapun tulangan kolom menggunakan tulangan utama D20 dan tulangan pengikat D12; balok menggunakan tulangan utama D25 dan tulangan pengikat D12; pelat lantai dan basement menggunakan tulangan D10; dan shear wall menggunakan tulangan D16 (arah 11) dan D20 (arah 22). Struktur penopang model 1 menggunakan tulangan yang sama dengan shear wall dan model 2 menggunakan tulangan yang sama dengan kolom. Jumlah tulangan utama dan jarak antartulangan beragam sesuai dimensi penampang elemen struktur.
\end{abstract}

Kata kunci :Beton Bertulang; Rental Office ; Rigid Frame; Kantilever; Detail Penulangan.

\begin{abstract}
Makassar City is increasingly characterized by a large number of multi-storey buildings, including office functions and building architectural design ideas that tend to vary the structure as an attractive design, the building structure is a major concern. reinforced concrete. The analysis aims to determine the exact structure details for the building with the SAP2000 program v.14. Research is quantitative because it determines the dimensions of the structure. The research is comparative. The cantilevered slab support structure is given two alternatives, namely model 1 and model 2. For earthquake loads, model 1 is more stable at 3.2\%-10.39\% of model 2. For earthquake loads, model 1 tends to be more stable with the greatest efficiency difference of $37.7 \%-45.4 \%$ in spectrum response earthquake load. The column reinforcement uses the main reinforcement D20 and reinforcement reinforcement D12; the beam uses the main reinforcement D25 and reinforcement reinforcement D12; floor plates and basements using D10 reinforcement; and the shear wall uses reinforcement D16 (direction 11) and D20 (direction 22). The support structure of model 1 uses the same reinforcement as the shear wall and model 2 uses the same reinforcement as the column. The number of main reinforcement and intermittent distances varies according to the cross-sectional dimensions of the structural elements.
\end{abstract}

Keywords: Reinforced Concrete; Rental Office; Rigid Frame; Cantilever; Repeat Details.

${ }^{1}$ Universitas Hasanuddin Makassar, Indonesia

${ }^{2}$ Universitas Hasanuddin Makassar, Indonesia

${ }^{3}$ Universitas Hasanuddin Makassar, Indonesia 


\section{PENDAHULUAN}

Seiring dengan kondisi Kota Makassar yang kepadatan penduduknya semakin meningkat tiap tahunnya, maka kebutuhan akan area bahkan ruang untuk beraktivitas semakin banyak. Bukan hanya hunian, ketersediaan ruang untuk melaksanakan aktivitas kerja secara formal (perkantoran) juga semakin sulit didapatkan, sehingga selain adanya fungsi apartemen untuk hunian, terdapat pula fungsi kantor sewa (rental office) sebagai bangunan tinggi (high rise) dengan unit-unit ruang yang dapat disewakan untuk menampung aktivitas bekerja secara formal dan kegiatan pertemuan (meeting) yang sifatnya lebih privat. Namun, bangunan high rise membutuhkan perencanaan yang lebih intensif karena strukturnya lebih rentan terhadap beban lateral (angin dan gempa) dan harus menopang beban sangat besar.

Adapun desain arsitektural bangunan kantor sewa (rental office) yang didesain menggunakan sistem struktur yang dapat memberi keunikan (daya tarik) tersendiri terhadap bentuk fasad bangunan, sehingga diterapkan sistem struktur core rigid frame berkantilever. Di samping itu, penelitian ini menggunakan material beton dengan tulangan baja sebagai material struktural yang sering digunakan karena efisien dan memiliki keseimbangan kuat tekan dan tarik yang baik namun, penggunaan material struktur ini pula membutuhkan analisis yang lebih kompleks agar dapat mencapai suatu struktur yang kokoh dan aman (safe). Hal ini membuat analisis struktural bangunan rental office 30 lantai memerlukan bantuan program (software) analisis struktur, yaitu CSI SAP2000 v.14.

Berdasarkan Gambar 1, perzoningan wilayah gempa di Indonesia terdiri dari zona 1 hingga zona 6 di mana zona 5 dan zona 6 merupakan zona paling rawan gempa. Karena penelitian ini bertempat di Kota Makassar, maka persamaan dan data tanah yang digunakan untuk melakukan analisis gempa disesuaikan dengan data tanah dari zoning 2 dan grafik respon spektrum Kota Makassar. Serta adapun untuk menahan beban-beban lateral (termasuk gempa) maka diterapkan kombinasi antara sistem rangka pemikul momen dan sistem dinding struktural disesuaikan jenis sistem core rigid frame berkantilever sebagaimana telah ditetapkan.

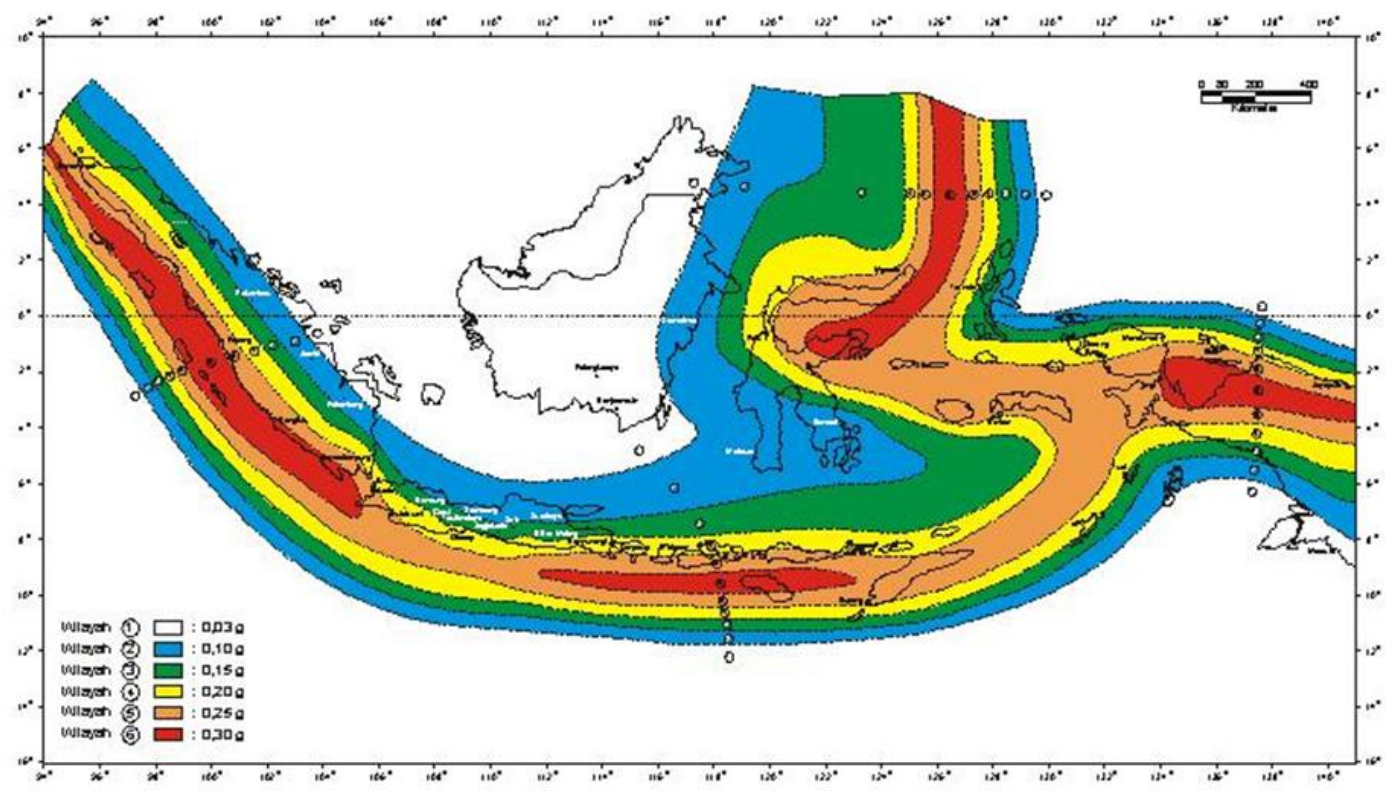

Gambar1 :Peta Zonasi Wilayah Gempa di Indonesia Sumber: Departemen Pekerjaan Umum, "SNI 03-1726-2002", 2002 
Perencanaan gedung dengan fungsi rental office 30 lantai dengan penerapan sistem core rigid frame berkantilever mengunakan komposisi struktur yang kokoh terutama terhadap bebanbeban lateral yang bekerja terhadap bangunan yang direncanakan karena bangunan high rise sangat rawan terhadap beban-beban lateral seperti angin dan gempa. Penelitian ini akan menggunakan kombinasi sistem rangka pemikul momen dan sistem dinding struktural. Jenis sistem struktur yang diterapkan pada bangunan ini memerlukan analisis dalam menentukan dimensi dan detail penulangan yang lebih spesifik.

Penelitian ini bertujuan untuk mendapatkan detail penulangan dan luas penampang tiaptiap elemen struktur (kolom, balok, dan pelat) mendapatkan nilai luasan kebutuhan penampang tulangan berdasarkan dimensi penampang tiap-tiap elemen struktur yang mampu menopang seluruh beban yang bekerja pada bangunan. Nilai kebutuhan tulangan ini menjadi dasar untuk menghasilkan gambar detail struktur (detail penulangan dan dimensi penampang struktur).

\section{METODE}

Penelitian ini bersifat kuantitatif. Metode yang digunakan dalam analisis struktur berbasis program (simulating), lalu data-data yang diperoleh diolah menjadi nilai dan jumlah kebutuhan tulangan struktur bangunan (developing). Literatur yang digunakan dalam penelitian ini dikelompokkan menjadi dua, yaitu literatur desain bangunan gedung sesuai fungsi (perkantoran) dan literatur struktur. Literatur desain yang digunakan berasal dari buku panduan, jurnal, dan skripsi tentang perancangan bangunan fungsi perkantoran. Literatur struktur yang digunakan berasal dari standar-standar yang berlaku di Indonesia tentang perencanaan struktur terhadap berbagai jenis pembebanan, termasuk gempa.

Analisis yang dilakukan dalam penelitian ini terkait dengan beban hidup, beban mati, dan beban angin yang bekerja pada bangunan.analisis penelitian ini juga terkait beban gempa menggunakan metode spektrum respons dan metode time history, di mana tahapan analisis dan perhitungan yang digunakan mengacu pada SNI 03-1726-2002. Analisis menggunakan program analisis struktur hingga mendapatkan nilai kebutuhan tulangan untuk tiap-tiap jenis elemen struktur bangunan, lalu jarak tulangan dhitung secara manual sesuai dengan luas penampang tiaptiap elemen struktur yang ditetapkan.

\section{HASIL DAN PEMBAHASAN}

Dalam menganalisis struktur bangunan diperlukan data-data dasar yang secara tidak langsung dapat berpengaruh terhadap analisis luasan penampang dan kebutuhan tulangan struktur yang dapat dipaparkan melalui tabel berikut ini.

Tabel 1. Data Dasar Struktur Bangunan

No Aspek Tinjauan Data Bangunan

\begin{tabular}{llll}
\hline 1 & Fungsi Bangunan & Rental Office 30 Lantai & \\
\hline 2 & Tinggi Per Lantai & Basement & $: 4 \mathrm{~m}$ \\
& & Podium & $: 5.5 \mathrm{~m}$ \\
& Tip. Tower & $: 4.5 \mathrm{~m}$ \\
& Skylobby + Maintenance : $6 \mathrm{~m}$
\end{tabular}




\begin{tabular}{lll}
\hline 3 & Sistem Struktur & Cantilevered Core Rigid Frame \\
\hline 4 & Material Struktur & Beton Bertulang \\
\hline 5 & Mutu Material Struktur & Mutu Beton f'c $=58.1 \mathrm{Mpa}(\mathrm{K}-700)$ \\
& & Mutu Baja Tulangan Ulir fy $=410 \mathrm{Mpa}$ \\
& & Mutu Baja Tulangan Polos fy $=240 \mathrm{Mpa}$ \\
\hline 6 & Letak & Kota Makassar (Zona 2 Wilayah Gempa) \\
\hline 7 & Jenis Tanah & Tanah Sedang \\
\hline 8 & Kombinasi Pembebanan & 1) $1,4 \mathrm{D}$ \\
& & 2) $1.2 \mathrm{D}+1.6 \mathrm{~L}$ \\
& & 3) $1.2 \mathrm{D}+\mathrm{L}+\mathrm{W}$ \\
& & 4) $1.2 \mathrm{D}+1.6 \mathrm{~L}+0.5 \mathrm{~W}$ \\
& & 5) $1.2 \mathrm{D}+\mathrm{L}+\mathrm{RSx}$ \\
& 6) $1.2 \mathrm{D}+\mathrm{L}+0.3 \mathrm{RSy}$ \\
\hline
\end{tabular}

Sumber: (Penulis, 2018) 2018

Bangunan rental office yang menjadi objek analisis struktural pada penelitian ini memiliki rata-rata dimensi $64.8 \times 64.8 \mathrm{~m}^{2}$ untuk area basement dan podium, serta $36 \times 43.2 \mathrm{~m}^{2}$ untuk area tower dengan desain seperti yang terlampir di bawah ini.

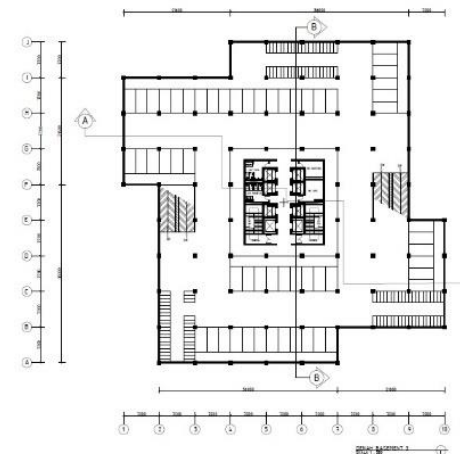

(1)

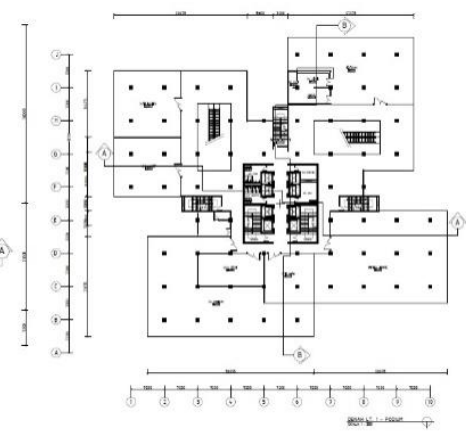

(2)

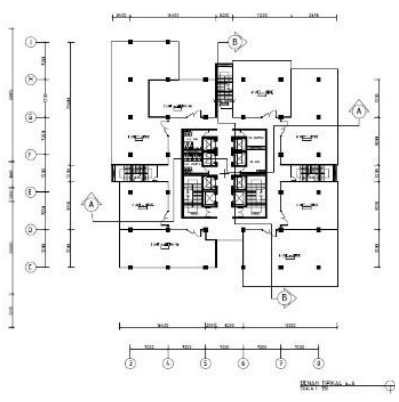

(3)

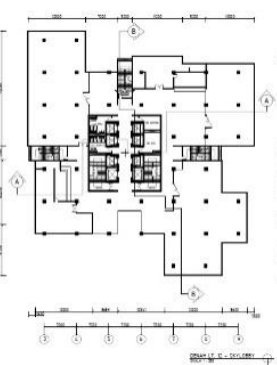

(4)

Gambar2 : 1.Denah Basement; 2. Denah Podium; 3. Denah Tower; 4. Denah Skylobby.

Sumber: Penulis, 2018

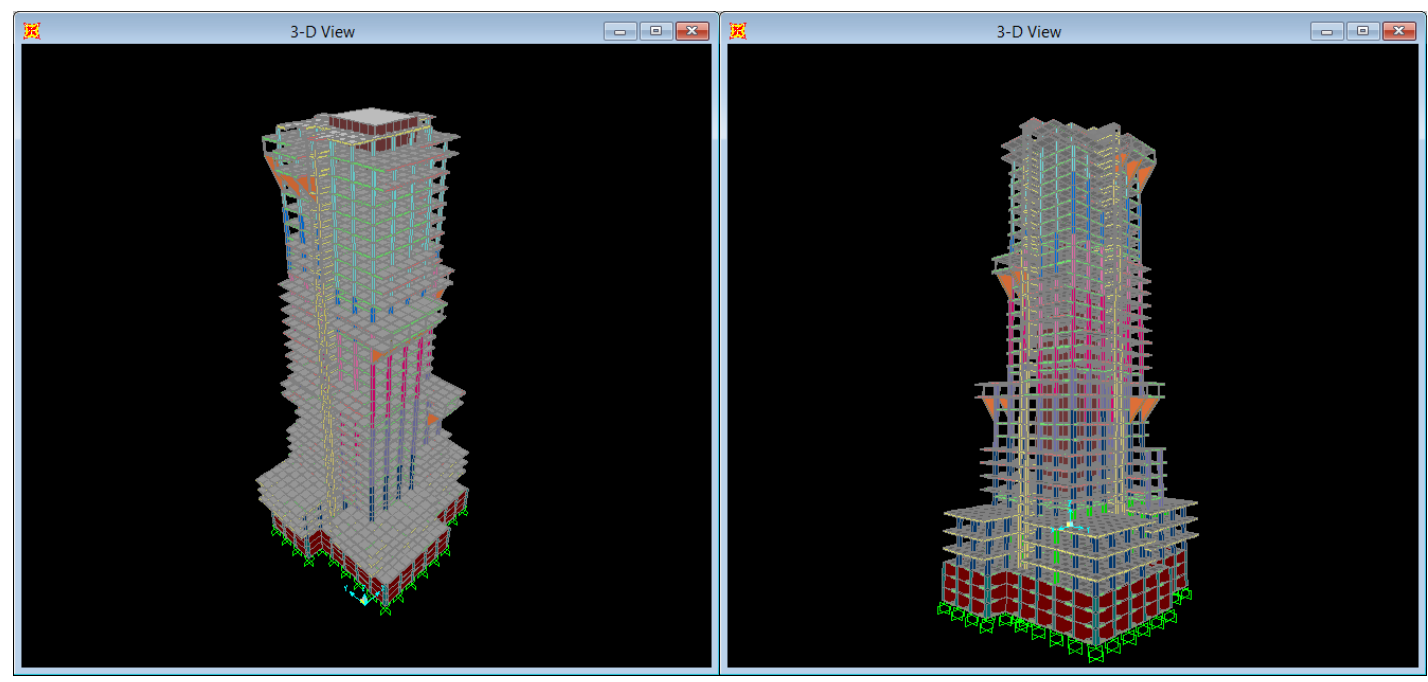

Gambar3 :Model 3D Struktur pada Program SAP2000. Sumber: Penulis, 2018 
Struktur cantilevered core rigid frame pada bangunan ini menggunakan modul struktur segiempat dengan bentangan modul $7.2 \times 7.2 \mathrm{~m}$. Jarak overstek terbesar penerapan struktur kantilever yang digunakan pada bangunan dalam penelitian ini sepanjang $7.2 \mathrm{~m}$. Pembebanan pada struktur bangunan dalam penelitian ini meliputi beban hidup, beban mati, beban angin, dan beban gempa. Output nilai pembesian dan dimensi penampang struktur yang akan dianalisis meliputi kolom, balok induk, balok anak, pelat lantai, dan shearwall. Permodelan struktur bangunan dalam penelitian ini menggunakan program analisis SAP2000 v.14.1.Adapun penelitian ini membandingkan efisiensi struktur penopang cantilevered sla $b$ pada bangunan antara model 1 (menggunakan konsol tebal) dan model 2 (menggunakanframe cabang dari kolom).

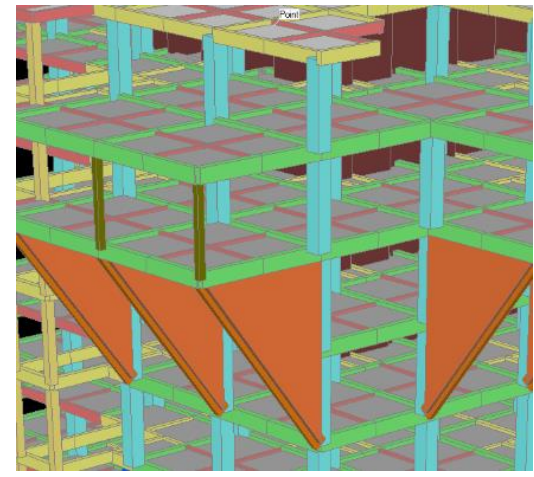

(1)

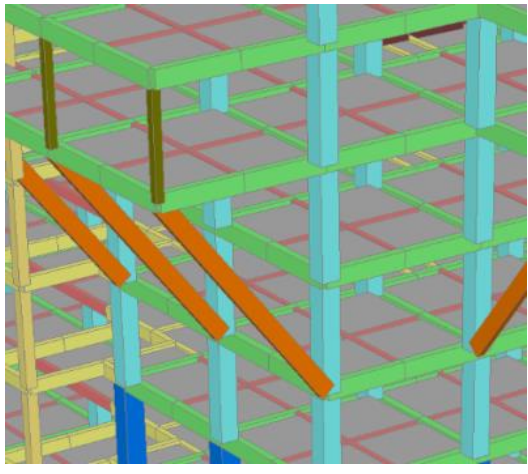

(2)

Gambar4 :3D Model Struktur Penopang Cantilevered Slab menggunakan 1. Konsol Tebal; 2. Frame Cabang Kolom Sumber: Penulis, 2018

Kedua jenis struktur penopang cantilever slab ini akan dibangingkan tingkat efisiensinya melalui perbandingan joint displacement berdasarkan tiap-tiap jenis beban yang direncanakan pada bangunan dalam penelitian ini. Adapun untuk analisis beban gempa, joint displacement juga dibandingkan dengan kinerja batas layan dan kinerja batas ultimit.

Kinerja batas layan merupakan batas yang ditentukan oleh simpangan antar-tingkat akibat pengaruh Gempa Rencana, yaitu untuk membatasi terjadinya pelelehan baja dan peretakan beton yang berlebihan, di samping untuk mencegah kerusakan non struktur dan ketidaknyamanan penghuni, di mana simpangan antar-tingkat yang dihitung dari simpangan struktur gedung tidak boleh melampaui $\frac{0,0 z}{\mathrm{R}}$ kali tinggi tingkat yang bersangkutan atau $30 \mathrm{~mm}$, bergantung yang mana yang nilainya terkecil. Sedangkan kinerja batas ultimit merupakan ditentukan oleh simpangan dan simpangan antar-tingkat maksimum struktur gedung akibat pengaruh Gempa Rencana dalam kondisi struktur gedung di ambang keruntuhan, yaitu untuk membatasi kemungkinan terjadinya keruntuhan struktur gedung yang dapat menimbulkan korban jiwa manusia dan untuk mencegah benturan berbahaya antar-gedung atau antar bagian struktur gedung yang dipisah dengan sela pemisah (sela delatasi). Kinerja batas ultimit struktur bangunan ditentukan 0,02 kali tinggi per lantai bangunan. Sehingga, perbandingan efisiensi struktur penopang cantilevered slab dapat dilihat melalui paparan berikut. 


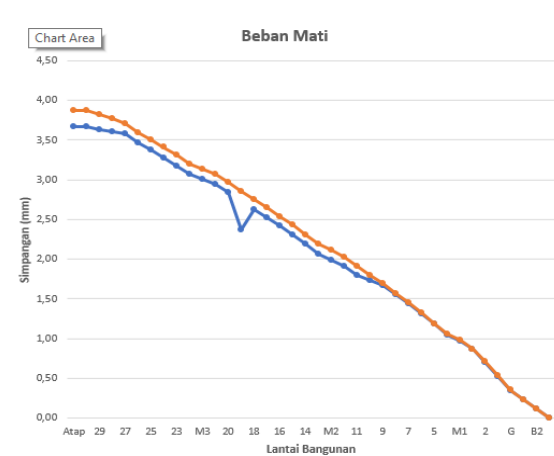

(1)

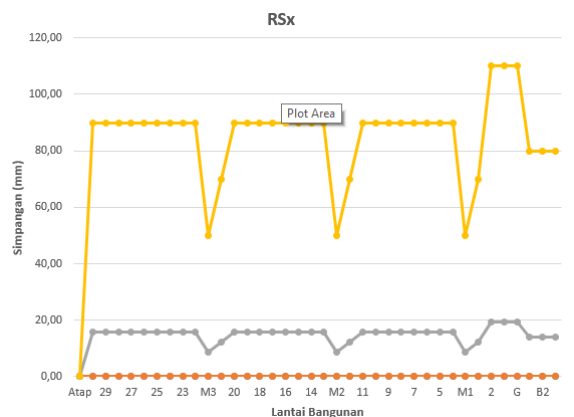

(4)

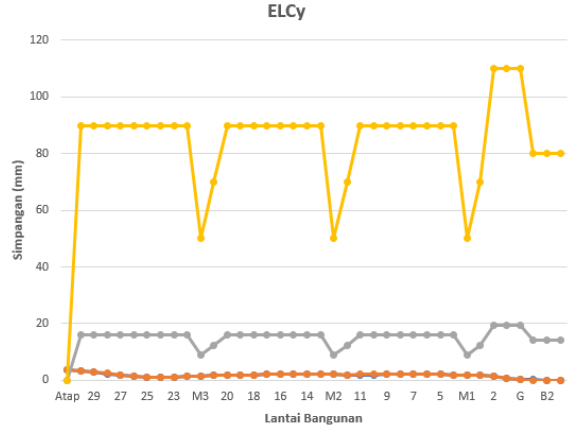

(7)

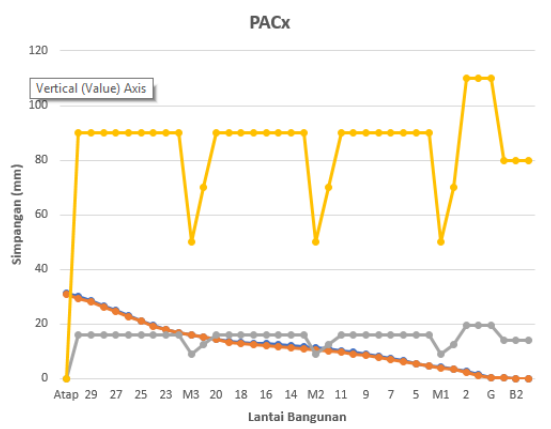

(10)

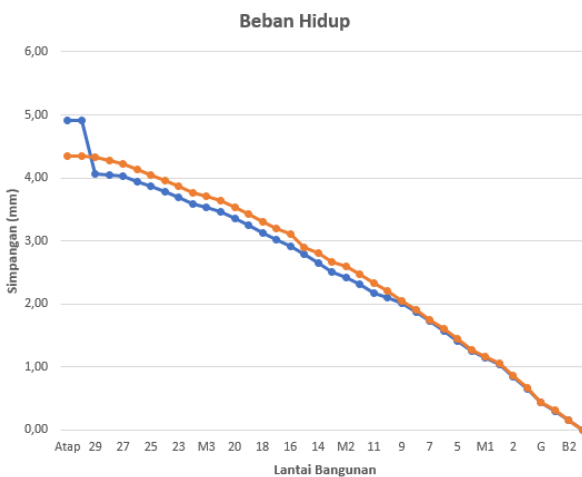

(2)

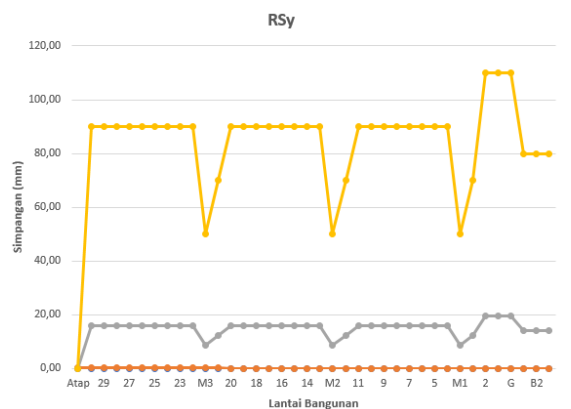

(5)

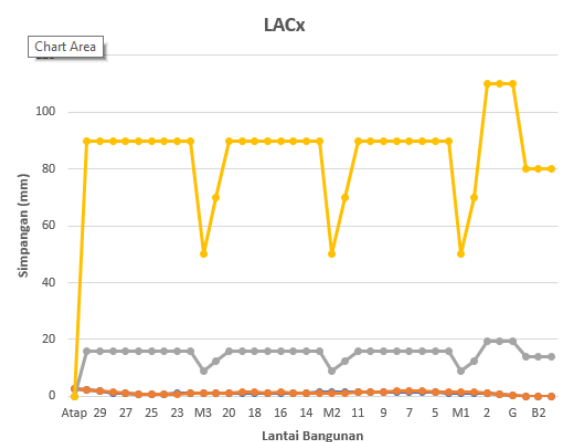

(8)

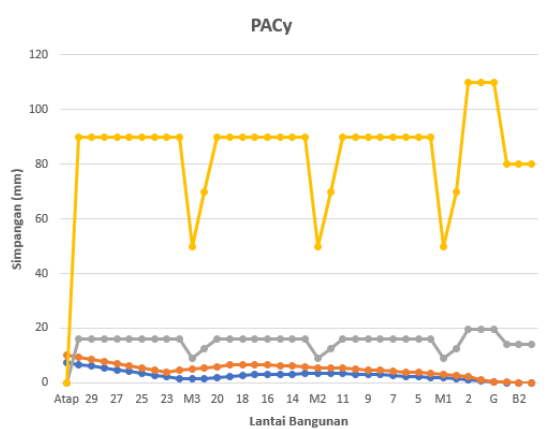

(11)

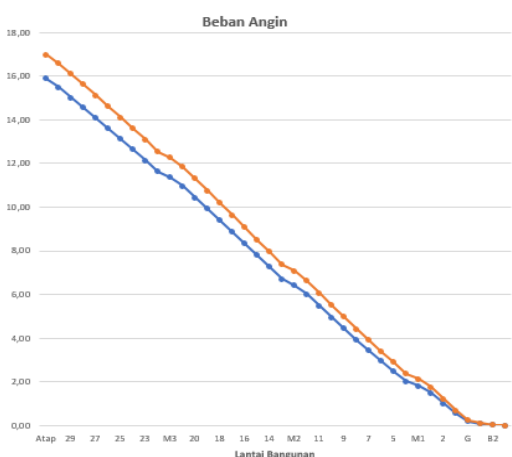

(3)

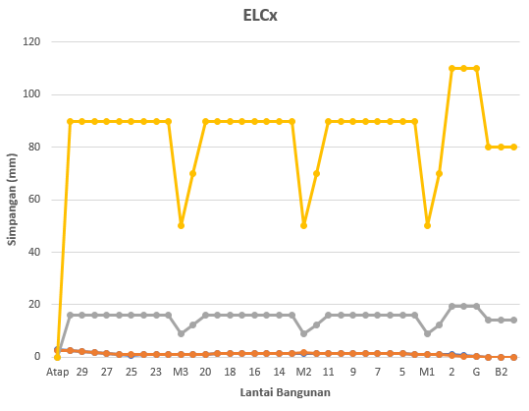

(6)

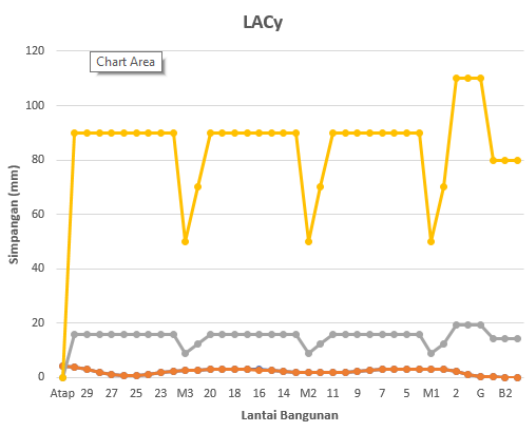

(9)

Gambar4 :Grafik Komparasi Joint Displacement model 1 dan 2 untuk beban: 1. Mati; 2. Hidup; 3. Angin; 4. Respon Spektrum X; 5. Respon Spektrum Y; 6. El Centro X; 7. El Centro Y; 8. LA Century City X; 9. LA Century City Y; 10. Pacoima X; 11. Pacoima Y; Sumber: Penulis, 2018 
Dari grafik-grafik tersebut dapat diperoleh bahwa

Tabel 2. Perbandingan Efisiensi Struktur Penopang Cantilevered Slab Berdasarkan Joint Displacement
No Jenis Beban
Tingkat Efisiensi

\begin{tabular}{cll}
\hline 1 & Beban Mati & Model 1 lebih efisien sebesar 3,44\% \\
\hline 2 & Beban Hidup & Model 1 lebih efisien sebesar 3,21\% \\
\hline 3 & Beban Angin & Model 1 lebih efisien sebesar 10,39\% \\
\hline 4 & Respon Spektrum Arah X & Model 1 lebih efisien sebesar 37,71\% \\
\hline 5 & Respon Spektrum Arah Y & Model 1 lebih efisien sebesar 45,4\% \\
\hline 6 & Gempa El Centro Arah X & Model 2 lebih efisien sebesar 0,364\% \\
\hline 7 & Gempa El Centro Arah Y & Model 1 lebih efisien sebesar 0,397\% \\
\hline 8 & Gempa LA Century City Arah X & Model 1 lebih efisien sebesar 2,44\% \\
\hline 9 & Gempa LA Century City Arah Y & Model 2 lebih efisien sebesar 0,36\% \\
\hline 10 & Gempa Pacoima DAM Arah X & Model 2 lebih efisien sebesar 3,04\% \\
\hline 11 & Gempa Pacoima DAM Arah Y & Model 1 lebih efisien sebesar 44,84\%
\end{tabular}

Sumber: (Penulis, 2018) 2018

Setelah membandingkan efisiensi dua macam struktur penopang cantilevered slab, maka ditentukan detail penulangan untuk tiap-tiap elemen struktur. Untuk penentuan detail penulangan pelat lantai, dilakukan tahapan berikut ini:

1) Penentuan jarak titik berat tulangan ke serat terluar bagian tarik $\mathrm{ds}=20+0,5 \mathrm{D}=20+0,5 \cdot 10=25 \mathrm{~mm}$.

2) Penentuan jarak tebal pelat efektif

$\mathrm{d}=\mathrm{h}-\mathrm{ds}=180-25=155 \mathrm{~mm}$ (untuk pelat lantai dan atap)

$\mathrm{d}=\mathrm{h}-\mathrm{ds}=210-25=185 \mathrm{~mm}$ (untuk pelat basement;

3) Penentuan nilai $K_{\text {maks }}$ sebagai nilai yang menjadi indikator kelayakan nilai $K$ pelat berdasarkan tebal efektifnya.

$$
K_{\text {maks }}=\frac{382,5 \cdot 0,85 \cdot f^{\prime} c \cdot(600+f y-225 \beta)}{(600+f y)^{2}}
$$

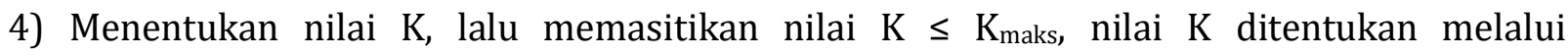
persamaan berikut.

$$
K=\frac{M_{u}}{\emptyset \cdot b \cdot d^{2}}
$$

5) Menentukan nilai a melalui persamaan berikut.

$a=\left(1-\sqrt{1-\frac{2 K}{0,85 f^{\prime} c}}\right) d$

6) Penentuan jarak antartulangan melalui persamaan berikut. $s=\frac{0,25 \cdot \pi \cdot D^{2} \cdot b \cdot f_{y}}{0,85 \cdot f^{\prime} c \cdot a \cdot b}$ 
Dari tahapan di atas, detail penulangan pelat lantai dapat ditentukan melalui tabel berikut ini. Tabel 3. Penentuan Detail Penulangan Lantai

\begin{tabular}{|c|c|c|c|c|}
\hline No & Jenis Pelat & $\begin{array}{l}\text { Tebal Pelat } \\
\quad(\mathbf{m m})\end{array}$ & $\begin{array}{c}\text { Luas Penampang } \\
\text { Tulangan }\left(\mathrm{mm}^{2}\right)\end{array}$ & Pola Penulangan \\
\hline 1 & Pelat Lantai & 180 & 78,5 (D10) & $\begin{array}{l}\text { a) Lapangan X : D } 10- \\
140 \\
\text { b) Tumpuam X:D10- } \\
60 \\
\text { c) Lapangan Y : D10 - } \\
140 \\
\text { d) Tumpuan Y : D } 10-60\end{array}$ \\
\hline 2 & Pelat Atap & 180 & 78,5 (D10) & $\begin{array}{l}\text { a) Lapangan X:D10- } \\
140 \\
\text { b) Tumpuam X:D10- } \\
60 \\
\text { c) Lapangan Y : D10 - } \\
140 \\
\text { d) Tumpuan Y : D } 10-60\end{array}$ \\
\hline 3 & Pelat Basement & 210 & 78,5 (D10) & $\begin{array}{l}\text { a) Lapangan X : D10- } \\
160 \\
\text { b) Tumpuam X:D10- } \\
60 \\
\text { c) Lapangan Y : D10- } \\
160 \\
\text { d) Tumpuan Y : D } 10-60\end{array}$ \\
\hline
\end{tabular}

Sumber: (Penulis, 2018) 2018

Kemudian, dilakukan penentuan detail penulangan pelat lantai, dilakukan tahapan berikut ini:

1) Penentuan jumlah tulangan utama.

$$
\begin{aligned}
& \mathrm{n}=\frac{F_{\text {top area }}}{A_{s}} \text { (untuk tulangan atas') } \\
& \mathrm{n}=\frac{F_{\text {bot area }}}{A_{s}} \text { (untuk tulangan bawah) }
\end{aligned}
$$

2) Penentuan jarak tulangan pengikat dengan persamaan berikut.

$$
\mathrm{n}=\frac{1000 \cdot A_{s}}{V_{\text {rebar }}}
$$

\begin{tabular}{|c|c|c|c|c|c|}
\hline No & $\begin{array}{l}\text { Jenis } \\
\text { Balok }\end{array}$ & $\begin{array}{l}\text { A }_{\text {s }} \text { Tulangan } \\
\text { Utama }\left(\mathbf{m m}^{2}\right)\end{array}$ & $\begin{array}{c}\mathbf{A}_{\mathrm{s}} \text { Tulangan } \\
\text { Pengikat }\left(\mathrm{mm}^{2}\right)\end{array}$ & $\begin{array}{c}\text { Pola Penulangan } \\
\text { Tumpuan }\end{array}$ & $\begin{array}{c}\text { Pola Penulangan } \\
\text { Lapangan }\end{array}$ \\
\hline 1 & $\begin{array}{l}\text { Balok } 1 \\
(360 x 7 \\
20 \mathrm{~mm})\end{array}$ & 490,5 (D25) & 113,04 (D12) & $\begin{array}{l}\text { a) Atas : 8 D25 } \\
\text { b) Bawah : } 4 \\
\text { D25 } \\
\text { c) Pengikat : }\end{array}$ & $\begin{array}{l}\text { a) Atas : 4 D25 } \\
\text { b) Bawah : } 8 \\
\text { D25 } \\
\text { c) Pengikat : }\end{array}$ \\
\hline
\end{tabular}

Dari tahapan di atas, detail penulangan balok lantai dapat ditentukan melalui tabel berikut ini. 


\begin{tabular}{|c|c|c|c|c|c|c|c|}
\hline & & & & & D12-125 & & D12-145 \\
\hline \multirow{5}{*}{2} & & & & a) & Atas : 8 D25 & a) & Atas : 8 D25 \\
\hline & Balok 2 & & & b) & Bawah : 4 & b) & Bawah : 4 \\
\hline & $(300 \times 6$ & 490,5 (D25) & 113,04 (D12) & & D25 & & D25 \\
\hline & $00 \mathrm{~mm})$ & & & c) & Pengikat : & c) & Pengikat : \\
\hline & & & & & D12- 125 & & D12 - 145 \\
\hline \multirow{5}{*}{3} & & \multirow{5}{*}{490,5 (D25) } & \multirow{5}{*}{113,04 (D12) } & a) & Atas : 6 D25 & a) & Atas : 3 D25 \\
\hline & Balok 3 & & & b) & Bawah : 3 & b) & Bawah : 6 \\
\hline & $(250 \times 4$ & & & & D25 & & D25 \\
\hline & \multirow[t]{2}{*}{$80 \mathrm{~mm})$} & & & c) & Pengikat: & c) & Pengikat: \\
\hline & & & & & D12-145 & & D12 - 170 \\
\hline
\end{tabular}

Sumber: (Penulis, 2018) 2018

Adapun untuk menentukan detail penulangan kolom dilakukan melalui tahapan berikut ini:

1) Penentuan jumlah tulangan utama melalui persamaan berikut ini.

$$
n_{\text {tulangan }}=\frac{[\text { PMM Rebar }]}{A_{s}}
$$

2) Penentuan jarak antartulangan pengikat melalui persamaan berikut ini.

$$
s=\frac{1000 \cdot A_{s} \cdot n_{f}}{V_{\text {rebar }}}
$$

Adapun dengan tahapan ini, dapat pula ditentukan pola penulangan struktur penopang cantilevered slab menggunakan frame cabang kolom (model 2). Dari tahapan di atas, detail penulangan kolom dapat ditentukan melalui tabel berikut ini.

\begin{tabular}{|c|c|c|c|c|c|}
\hline No & $\begin{array}{l}\text { Jenis } \\
\text { Kolom }\end{array}$ & $\begin{array}{c}\text { As Tulangan } \\
\text { Utama }\left(\mathrm{mm}^{2}\right)\end{array}$ & $\begin{array}{c}A_{\mathrm{s}} \text { Tulangan } \\
\text { Pengikat }\left(\mathrm{mm}^{2}\right)\end{array}$ & $\begin{array}{c}\text { Jumlah Tulangan } \\
\text { Utama }\end{array}$ & $\begin{array}{c}\text { Pola Tulangan } \\
\text { Pengikat }\end{array}$ \\
\hline 1 & Kolom K1 & 314 (D20) & 113,04 (D12) & $\begin{array}{l}\text { a) K120x120:48 } \\
\text { D20 } \\
\text { b) K110x110:40 } \\
\text { D20 } \\
\text { c) K100x100:32 } \\
\text { D20 } \\
\text { d) K90x90: 28 D20 } \\
\text { e) K80x80:24 D20 }\end{array}$ & $\mathrm{D} 12-80$ \\
\hline 2 & Kolom K2 & 314 (D20) & 113,04 (D12) & $8 \mathrm{D} 20$ & D12 -250 \\
\hline 3 & Kolom K3 & $314(\mathrm{D} 20)$ & $113,04(\mathrm{D} 12)$ & $\begin{array}{l}\text { a) K95x95: 28 D20 } \\
\text { b) K80x80:24 D20 } \\
\text { c) K65x65:16 D20 } \\
\text { d) K50x50:12 D20 }\end{array}$ & $\begin{array}{l}\text { e) K95x95:D12 - 80 } \\
\text { f) K80x80:D12 - 80 } \\
\text { g) K65x65:D12- } \\
145 \\
\text { h) K50x50:D12 - } \\
200\end{array}$ \\
\hline
\end{tabular}

Tabel 4. Penentuan Detail Penulangan Kolom

\begin{tabular}{|c|c|c|c|c|c|}
\hline & Kolom & & & & \\
\hline 4 & $\begin{array}{l}\text { Tumpuan } \\
\text { Kantilever }\end{array}$ & 314 (D20) & 113,04 (D12) & $12 \mathrm{D} 20$ & D12 - 250 \\
\hline
\end{tabular}


Serta, terdapat pula tahapan dalam menetukan detail penulangan shear wall dari core dan konsol tebal sebagai struktur penopang cantilevered slab yang dipaparkan sebagai berikut.

1) Menentukan luas penampang total kebutuhan tulangan per $m$ bentang shear wall atau konsol dengan persamaan berikut ini.

$$
\begin{gathered}
A_{S} S=\frac{S \cdot A_{c}}{\emptyset \cdot f_{y}} \text { (untuk tulangan tulangan lapangan) } \\
A_{S} S=\frac{\left(S-\emptyset \cdot f^{\prime} c\right) \cdot A_{c}}{\emptyset \cdot f_{y}} \text { (untuk tulangan tulangan tumpuan) }
\end{gathered}
$$

2) Menentukan jarak antartulangan melalui persamaan berikut ini.

$$
l=\frac{1000 \cdot A_{s}}{A_{s} S}
$$

Sehingga dari tahapan di atas, detail penulangan shear wall dan konsol tebal sebagai

\begin{tabular}{|c|c|c|c|c|c|}
\hline No & $\begin{array}{c}\text { Tebal } \\
\text { Shear Wall } \\
(\mathrm{mm})\end{array}$ & $\begin{array}{c}A_{s} \text { Tulangan } \\
\text { Arah } 11 \\
\left(\mathrm{~mm}^{2}\right)\end{array}$ & $\begin{array}{c}\text { As Tulangan } \\
\text { Arah } 22\left(\mathbf{m m}^{2}\right)\end{array}$ & $\begin{array}{c}\text { Pola Tulangan Arah } \\
\qquad 11\end{array}$ & $\begin{array}{c}\text { Pola Tulangan Arah } \\
\qquad 22\end{array}$ \\
\hline 1 & 300 & 200.96 (D16) & 314 (D20) & $\begin{array}{l}\text { D16 - } 150 \text { (tumpuan } \\
\text { dan lapangan) }\end{array}$ & $\begin{array}{l}\text { D20 - } 250 \text { (tumpuan } \\
\text { dan lapangan) }\end{array}$ \\
\hline 2 & 250 & 200.96 (D16) & 314 (D20) & $\begin{array}{l}\text { D16 - } 150 \text { (tumpuan } \\
\text { dan lapangan) }\end{array}$ & $\begin{array}{l}\text { D20 - } 250 \text { (tumpuan } \\
\text { dan lapangan) }\end{array}$ \\
\hline 3 & 200 & 200.96 (D16) & 314 (D20) & $\begin{array}{l}\text { D16 - } 150 \text { (tumpuan } \\
\text { dan lapangan) }\end{array}$ & $\begin{array}{l}\text { D20 - } 300 \text { (tumpuan } \\
\text { dan lapangan) }\end{array}$ \\
\hline 4 & $\begin{array}{c}450 \\
\text { (Konsol } \\
\text { Tumpuan } \\
\text { Kantilever) }\end{array}$ & 200.96 (D16) & 314 (D20) & $\begin{array}{l}\text { D16 - } 150 \text { (tumpuan } \\
\text { dan lapangan) }\end{array}$ & $\begin{array}{l}\text { D20 - } 250 \text { (tumpuan } \\
\text { dan lapangan) }\end{array}$ \\
\hline
\end{tabular}
tumpuan cantilevered slab dapat ditentukan melalui tabel berikut ini.

Tabel 5. Penentuan Detail Penulangan Shear Wall

Sumber: (Penulis, 2018) 2018

\section{KESIMPULAN}

Analisis terhadap Perencanaan struktur beton bertulang untuk desain bangunan rental office 30 lantai dengan penekanan struktur cantilevered core rigid frame ini merupakan analisis yang dilakukan untuk struktur rigid frame dengan penerapan cantilevered slab dengan jarak overstek yang berbeda-beda. Yang baru dan berbeda dari penelitian ini, yaitu jarak overstek dari cantilevered slab yang diterapkan bervariasi, antara lain $2 \mathrm{~m} ; 3,6 \mathrm{~m}$ (1/2 bentangan modul); hingga 7,2 $\mathrm{m}$ (1 bentangan modul), sehingga menjadi daya tarik struktural terhadap bentuk bangunan dan membutuhkan analisis struktur beton bertulang yang lebih efektif. Struktur penopang cantilevered slab pada bangunan ini diberi dua alternatif, antara lain struktur penopang menggunakan konsol tebal (model 1) dan menggunakan frame cabang dari kolom (model 2). Dalam penelitian ini, kedua macam alternatif struktur dibandingkan efisiensinya dan dianalisis tulangannya.

Dari hasil analisis perbandingan efisiensi antara alternatif model 1 dan model 2, dapat disimpulkan bahwa struktur penopang cantilevered slab model 1 (menggunakan konsol tebal) lebih efisien dari model 2 (menggunakan frame cabang kolom). Hal ini kurang nampak pada beban- 
beban nongempa karena selisih efisiensinya tipis, namun selisih efisiensinya lebih nampak pada beban gempa. Adapun untuk tulangan kolom menggunakan baja D20 sebagai tulangan utama dan D12 sebagai tulangan pengikat; balok menggunakan tulangan D25 sebagai tulangan utama dan D12 sebagai tulangan pengikat; pelat lantai dan basement menggunakan tulangan D10; dan tulangan shear wall menggunakan tulangan D16 untuk arah 11 dan D20 untuk arah 22. Struktur penopang cantilevered slab model 1 menggunakan tulangan yang sama dengan shear wall dan model 2 menggunakan tulangan yang sama dengan kolom. Jumlah tulangan utama dan jarak antartulangan beragam sesuai dengan dimensi penampang elemen struktur yang telah dibutuhkan.

Berdasarkan analisis dalam penelitian ini, terdapat saran-saran yang diajukan untuk penelitian yang lebih spesifik, yaitu analisis struktur terhadap desain arsitektural suatu bangunan akan lebih bagus jika menggunakan bentuk yang lebih dinamis dan menggunakan tulangan baja profil untuk lebih memperdalam ilmu mengenai perencanaan struktur bangunan yang bentuknya dinamis dan material bangunannya lebih baru. Serta, gunakan program analisis struktur berlisensi resmi agar hasil yang diperoleh lebih akurat.

\section{DAFTAR REFERENSI}

D. Bayyinah. "Studi Perbandingan Analisis Respon Spektra dan Time History untuk Desain Gedung" Jurnal Teknik ITS 6, no. 1 (2017): c33-c38

Maria CP. "Perencanaan Struktur Gedung Hotel Jalan Martadinata Manado" Jurnal Sipil Statik 4, no. 4 (2016): 263-270.

Rendra, Rezki. "Kinerja Struktur Akibat Beban Gempa dengan Metode Respon Spektrum dan Time History" JOM FKTEKNIK 2, no. 2 (2015): 1-15.

Sendi Septian RS. "Perencanaan Struktur Gedung Asrama Mahasiswa Universitas Sriwijaya Palembang dengan Penahan Lateral Kombinasi Sistem Rangka Pemikul Momen dan Dinding

Struktural"Jurnal Teknik Sipil dan Lingkungan 2, no. 1 (2014): 139-145

Dipohusodo. (1994). Struktur Beton Bertulang. Jakarta: Gramedia

Juwana. (2005).Panduan Sistem Bangunan Tinggi. Jakarta: Erlangga

Mosley dan Bungley. (1987). Reinforced Concrete Design. London: Macmillan Press Ltd.

Poerbo. (2007). Utilitas Bangunan: Buku Pintar untuk Mahasiswa Arsitektur-Sipil. Jakarta: Djambatan Peraturan Beton Bertulang Indonesia (PBI 1971)

SNI 03-2847-2002 tentang Pedoman Perhitungan Struktur Beton untuk Bangunan Gedung SNI 03-1726-2002 tentang Tata Cara Perencanaan Ketahanan Gempa untuk Bangunan Gedung

SNI 1726-2002 tentang Pedoman Perhitungan Struktur Beton untuk Bangunan Gedung 